\title{
A comprehensive review of the application of plasma gasification technology in circumventing the medical waste in a post-COVID-19 scenario
}

\author{
Rajneesh Kaushal ${ }^{1}$ (D) $\cdot$ Rohit $^{2} \cdot$ Amit Kumar Dhaka $^{3}$
}

Received: 17 November 2021 / Revised: 29 January 2022 / Accepted: 3 February 2022

(c) The Author(s), under exclusive licence to Springer-Verlag GmbH Germany, part of Springer Nature 2022

\begin{abstract}
The recent COVID-19 pandemic, which has hit the world, is third in the last two decades. The safety and precaution measures have led to the generation of a colossal pile of biomedical waste, including plastic waste, due to the usage of personal protective equipment kits and safety equipment that is not easily manageable. The environment and health and safety concerns for humans require biomedical waste to be treated with an outstanding treatment process that can help humanity manage it by adhering to strict environmental norms prescribed. The plasma gasification technology is the most beneficial and efficient technology for treating biomedical waste. The byproducts generated can be utilized further as valuable inputs in other industries, thus strengthening the circular economy concept. In this research paper, the applicability of plasma gasification for the treatment of biomedical waste in the present scenario has been reviewed. The feasibility and applicability of the technology in handling biomedical waste have been reviewed via various research articles in this study. Also, further steps have been suggested for the Indian scenario to make this technology commercially viable in the long run.
\end{abstract}

Keywords COVID-19 - Biomedical waste $\cdot$ Biomedical waste treatment methods · Plasma gasification · Efficiency · Synthesis gas

\begin{tabular}{l} 
Abbreviations \\
BMW Biomedical waste \\
CAGR Compounded annual growth rate \\
CPCB Central Pollution Control Board \\
\hline Highlights \\
- COVID-19 pandemic reported 356 million cases globally with \\
a staggering rise in biomedical waste. \\
- India has recorded a rise of 200 tons per day of biomedical waste \\
generation due to pandemics. \\
- The share of plastic has increased in biomedical waste due to \\
masks, gloves, PPE kits, etc. \\
- Plasma gasification has emerged as an attractive and viable \\
option to treat biomedical waste.
\end{tabular}

Rajneesh Kaushal rajneesh@nitkkr.ac.in

Rohit

rohit.iitb21@gmail.com

1 Department of Mechanical Engineering, NIT Kurukshetra, Haryana, India

2 Environmental Science and Engineering Department, IIT, Bombay, India

3 School of Renewable Energy and Efficiency, NIT Kurukshetra, Haryana, India

$\begin{array}{ll}\text { DC } & \text { Direct current } \\ \text { FLW } & \text { Food loss and waste } \\ \text { GHG } & \text { Greenhouse gas } \\ \text { ICP } & \text { Inductively coupled plasma } \\ \text { MSW } & \text { Municipal solid waste } \\ \text { O\&M } & \text { Operation and maintenance } \\ \text { PG } & \text { Plasma gasification } \\ \text { PPE } & \text { Personal protective equipment } \\ \text { RF } & \text { Radiofrequency } \\ \text { SUP } & \text { Single-use plastics } \\ \text { UN } & \text { United Nation } \\ \text { UNEP } & \text { United Nation Environment Programme } \\ \text { WHO } & \text { World Health Organization }\end{array}$

\section{Introduction}

The rapid increase in population and ever-increasing zeal of humankind to get more acculturate in an urban environment has put more pressure on the available natural resources throughout the world. These resources have accumulated in nature, going through different processes and syntheses in millions of years. Human beings compete 
with wildlife to get a more massive chunk and convert these available raw resources to suitable usage. It has led to the growing interaction between humans and animals, which are vectors of disease, viruses, and bacteria that were unknown to society to date. Humanity has exploited the animals residing in their natural habitat in the wild and dismantled their habitats, making humans more vulnerable to zoonotic diseases [1].

In the last two decades, the world has seen three pandemic outbreaks due to coronavirus. The first one was a severe acute respiratory syndrome, also termed SARS-CoV-1, in 2002. The second one was Middle East Respiratory Syndrome, termed MERS-CoV in 2012. COVID-19 is the third one in the series that emerged in 2019 [2]. Interconnection between different countries of the world as a result of globalization and the capability of the COVID virus to spread faster has led to the outbreak declared as a pandemic by the WHO in March 2020 [3].

There has been a rapid increase in people residing in cities. As per the UN study, 54\% of the world's population resided in cities or urban areas [4]. India is catching pretty fast, considering the urbanization of its population due to fast economic growth. The transformation is primarily due to shifting the economy from agriculture-based to industry and service-based economy. Around $31.16 \%$ of people resided in urban areas as per the 2011 survey [5], crossing the 69\% mark by 2050 [6].

India is slowly proceeding towards a more urbanized society, and resulting waste generation in India is observing a rapid climb. Municipal solid waste (MSW) generation has increased from 31 million tons in 2001 to 62 million tons in 2015 in just 14 years, reaching 165 million tons by 2030 [7]. India is ranked fifth in the list of countries with an overall waste generation of approximately 0.12 million tons per day in 2016 and is set to increase by 5\% every year [8]. India's per capita MSW generation varies between 0.17 and $0.62 \mathrm{~kg}$ per person per day for small towns and big cities, respectively [9].

Indian cities face unplanned urbanization and are coupled with expeditious population growth and a poor standard of living. Around $90 \%$ of MSW generated in India is either non-attended or disposed of very poorly in an unscientific way [10]. As per Municipal Solid Waste (Management and Handling) Rules, 2000 made by the Government of India, municipal bodies are made responsible for proper collection, segregation, and treatment of waste. Municipal bodies in India have poor budgetary and technical support and lack adequate infrastructure for sustainable waste disposal. The persons engaged have poor coordination among themselves. They lack proper training and guidance to build sustainable strategies for appropriate waste disposal. Therefore, dumping waste in open mismanaged landfills outside the city limits in low-lying areas is a ubiquitous sight. This type of waste disposal in an unorganized way is an open invitation to significant health risks and epidemics [11].

The biomedical waste (BMW) generation has observed a staggering rise during the past decades, mainly due to increased healthcare access to more populations [12]. Usage of disposable items like injections, syringes, sample containers, gloves, shields, and personal protective equipment (PPE) kits has been increased as a precaution against diseases like COVID-19, SARS, AIDS, EBOLA, hepatitis, and tuberculosis.

The biomedical waste is managed as per the BMW rules notified by the Government of India in 2018. It reached a value of 435.3 tons per day in 2015 , translating approximately to $0.5-2 \mathrm{~kg}$ of waste per bed per day [13]. They are recycled, reduced at source, put into landfills, or incinerated under a properly controlled atmosphere. Souza et al. [14] have studied the cost of medical waste disposal in India and found that it can vary from Rs. 7.7 per bed per day to Rs. 12.4 per bed per day, depending on the type of healthcare facility. The biomedical waste management market was set to reach $\$ 10.3$ billion in 2018 for the USA itself, with a compounded annual growth rate (CAGR) of $4.9 \%$ [15].

India is all set to generate around 775 tons per day of biomedical waste in 2022, with current levels being 551 tons per day. ASSOCHAM has estimated a CAGR of about 7\% at this level of waste generation. United Nation Environment Programme (UNEP) study has estimated that due to the COVID pandemic, an increase of around $0.5 \mathrm{~kg}$ per bed per day of BMW is expected [16]. China has experienced a surge of $600 \%$ in medical waste generation, i.e., from 40 to 240 tons per day in Wuhan City only [17]. Asian capital cities such as Kuala Lumpur, Bangkok, and Manila were poorly hit, and medical waste generation increased from 154 to 280 tons per day [18].

Gasification is a process of thermochemical conversion of biomass waste into combustible gas at high temperatures in the presence of the gasifying medium. Sharma and Kaushal [19] discussed the economic feasibility of gasification technology for waste management in their research article. Gasification is very flexible in terms of waste acceptance as it can proceed with a myriad of feedstock, and the output gas can be utilized for a range of applications. The gasification technology has a promising aspect as it can be helpful in waste management, reducing GHG emissions and providing energy security. Plasma gasification of waste is a thermal treatment in which temperatures as high as $10,000 \mathrm{~K}$ vaporize the waste [20]. The resultant product is synthesis gas, efficiently running compression ignition engines in various applications. Plasma gasification technology provides a feasible and environment-friendly solution for biomedical waste treatment [21, 22].

Various authors have reported varying percentages of synthesis gas production during waste treatment using plasma 
gasification (PG). Messerle et al. [23] have treated biomedical waste using air plasma and steam plasma gasification and reported that synthesis gas ranging from 53.4 to 84.9 vol.\% could be produced. They have obtained a maximum yield at a temperature less than $1600 \mathrm{~K}$. A thermodynamic analysis conducted on the treatment of BMW in a plasma gasifier [22] has yielded syngas of the lower heating value $13 \mathrm{MJ} /$ $\mathrm{kg}$. The calorific value of syngas was almost double as what we observed in conventional gasification yields. The gas turbine system coupled with the plasma gasifier in the above study can offset more than half of the electricity required for operating the gasifier. A cold gas efficiency of $78.61 \%$ is observed in treating biomedical waste using PG [20]. The above study has established the possibility of utilizing PG for biomedical waste disposal and hydrogen production.

The PG technology has been beneficial as it can strengthen the circular economy concepts in the waste disposal scenario [24]. There are very few studies depicting the application of plasma gasification of biomedical waste. However, a comprehensive study after the COVID-19 pandemic to explore the applicability of plasma gasification depicting all the aspects is needed, which has been explored in this work. Authors have gone through recent and previously published articles to present the idea systematically. The entire article has been organized into various sections and subsections to present the topic comprehensively. This work will fulfill the quest of the scientific and research community to obtain structured information on PG of biomedical waste.

\section{Plasma gasification}

\subsection{Plasma gasification background}

Plasma is an electrified gas that exists in ions and electrons and becomes electrically conductive when the gas atoms are energized via electric current or by providing very high thermal energy. Plasma has several distinct characteristics concerning gases. Gases are electrical insulators that do not respond to electric and magnetic fields, whereas plasma is the opposite. Due to these characteristics, plasma qualifies to be called the fourth state of matter. The plasma was initially utilized in Apollo space programs of NASA in the 1960s. The plasma was first used in a small-scale plant to gasify municipal solid waste in Japan in the late 1990s. The experiment successfully led to full-scale commercial plants in various countries. Plasma can be classified as thermal plasma or non-thermal plasma. Thermal plasma has electrons and heavier particles such as ions and neutrons in thermal equilibrium with each other, that is, both of them are at the same temperature. Non-thermal plasma has electrons at a higher temperature than ions and neutrons. The degree of ionization is used to distinguish between these two plasmas. The degree of ionization is the ratio of charged particles to the total number of particles present in the plasma. Nonthermal plasma has a degree of ionization less than $10^{-4}$.

The energy associated with plasma which is transferred to the target feedstock for heating and melting consists of the difference between convective heat given to the target and radiative heat loss from the target to the surrounding. The net energy transferred to the feedstock, $Q_{i}$, is given by Eq. 1 [25].

$Q_{i}=h A\left(T_{\mathrm{p}}-T_{\mathrm{sf}}\right)-\sigma \varepsilon\left(T_{\mathrm{sf}}^{4}-T_{w}\right)$

where $h$ is the convective heat transfer coefficient between plasma and feedstock, $A$ is the surface area of the plasma interaction with feedstock, $T_{\mathrm{sf}}$ is the feedstock surface temperature, $T_{\mathrm{w}}$ is the wall temperature of the reactor shell, $\sigma$ is the Stefan-Boltzmann constant, and $\varepsilon$ is the emissivity of the feedstock.

The plasma is generated in a particular instrument called a plasma torch. The plasma torches utilize electrical energy supplied to the gas passing through it at particular pressure and temperature. The gas is excited due to its energy, and electrons are separated from gaseous atoms. These gaseous electrons collide with atoms to ionize the gas. The plasma generation is initiated once the ionization reaches a threshold limit. The system resistance plays an essential role in raising plasma temperature [26].

Plasma production can be done by utilizing different setups of plasma torches. Arc plasma (direct current (DC) transferred and non-transferred), radiofrequency (RF), microwave, and inductively coupled plasma torches are some of the methods exploited for this purpose. DC-transferred plasma torches have feedstock placed in the metal bath to work as counter electrodes, whereas DC-non-transferred torches have counter electrodes positioned inside the torch itself. Hybrid plasma setup consisting of arc plasma and RF plasma sources is being considered for many applications, including operating cost reduction and several added benefits. Comparison between different methods is provided in Table 1 for proper consideration of plasma torches.

\subsection{Introduction to technology}

Plasma gasification technology is a high-temperature decomposition of waste that converts the input feedstock into a valuable combustible gas called synthesis gas. The reaction takes place inside the reactor shell at a temperature as high as $3500-6500{ }^{\circ} \mathrm{C}[29,30]$, utilizing the thermal energy of the plasma. The waste decomposition proceeds at a very high rate in the limited oxygen supply due to the high temperature involved in the process. Plasma gasification can handle 
Table 1 Comparison of different types of plasma setups (sources: [27, 28])

\begin{tabular}{lllll}
\hline Parameters & DC transferred & DC non-transferred & Radiofrequency & Microwave \\
\hline Temperature (K) & $12,000-20,000$ & $10,000-14,000$ & $3000-8000$ & 5273 \\
Power input (kW) & Up to 80 & Up to 80 & 30 to 35 & No \\
Electrode erosion & Yes & Yes & No electrode & No \\
Electrode material & Graphite, copper & Graphite, brass, tungsten & Not required & Not required \\
Cooling method & Required & Not required & Ar, $\mathrm{O}_{2}, \mathrm{H}_{2}$ & $\mathrm{Not}_{2}$ required $\mathrm{H}_{2}, \mathrm{~N}_{2}$ \\
Plasma gas & $\mathrm{N}_{2}$, Ar, $\mathrm{CO}_{2}$, air & $\mathrm{N}_{2}$, Ar, air, $\mathrm{CO}_{2}, \mathrm{H}_{2} \mathrm{O}$ & Not required \\
Input waste conductivity & Required & Not required & $40-50$ & $\sim 5-100$ \\
Thermal efficiency $(\%)$ & $70-95$ & $70-95$ & $\sim 10,000$ & $\sim 2000$ \\
$1 \mathrm{~kW}$ plasma source unit cost (USD) & $\sim 500$ & $\sim 500$ & & \\
\hline
\end{tabular}

hazardous and non-hazardous waste, making it suitable for managing biomedical waste [29].

Plasma gasification setup consists of a reactor shell coupled with a waste feeding system. The waste feeding system has a hopper for continuous waste supply and a shredder for uniform particle size. The plasma torches are set up in the reactor shell at different positions depending on the size of the reactor shell. The feedstock waste enters into the reactor shell via a waste feeding mechanism. Shredder provides for uniform particle size for proper heat dispensation inside the shell. The plasma torches situated inside the reactor shell are like a tubular setup that produces an electric arc. Torches have two electrodes separated from each other with passage for gas in between them. The gas gets ionized with the flow of heavy electricity in between the two electrodes. This results in the ionization of gas, resulting in plasma formation. The heat is transferred from plasma to the waste feedstock inside the reactor shell. A temperature as high as 5500 ${ }^{\circ} \mathrm{C}$ is generated inside the reactor shells, mainly depending on the power source. Plasma has the advantage of being invariable with the feedstock type used, and it does not vary with the supply of oxygen or air into the system. The feedstock is subjected to a very high temperature, which converts into a combustible gas known as synthesis gas with carbon monoxide, hydrogen, and methane as its main constituents.

The carbonaceous and volatile part of the feedstock is gasified into syngas [31], while the inorganic compounds and polymer are melted to form a glass-like structure called a glass-like structure vitrified slag. The slag has various usages and contributes as raw materials for tiles, road construction, and landscaping. The metals cannot tolerate such high heat, and they can be quickly recovered in molten form for further usage. The plasma gasification can be extremely helpful for bulky waste as the volume reduction percentage is very high in the range of $95 \%$ [32]. The plasma gasification setup is shown in Fig. 1.

The gasifier reactor shell is attached with a slag removal system at the bottom to remove slag continuously. The syngas flows from the upper portion and enters the water scrubber for conditioning and cooling. After that, it enters the cyclone separator for the removal of particulates. Test flare is provided to check the combustibility of syngas. Syngas is utilized further for various applications after a stable and colorless flame is observed in the test flare setup. The entire process can be optimized for reactor temperature, waste feeding rates, the power supplied to the setup, and the rate of slag elimination [33]. The gas constituents can be optimized to obtain syngas rich in combustible species like carbon monoxide, hydrogen, and methane. The schematic sketch depicting the overall process of waste to energy using plasma gasification is shown in Fig. 2.

Plasma gasification has the advantage that its high temperature can destroy any active ingredient compounds, radicals, and harmful radioactive materials apart from the benefits of conventional gasification. The syngas produced has very low contaminants, but nanoparticles in the syngas can be a problem [34]. The major demerit is that plasma gasification is an energy-intensive process. The average efficiency for plasma gasification is $42 \%$, which is very low compared with convention gasification, in which efficiency can go as high as up to $72 \%$ [35].

\section{Biomedical waste}

\subsection{Biomedical waste generation}

BMW is waste generated by medical practices like diagnosis and treatment; research carried out on human and animal samples; and medicinal composition and residues, pharmaceutical products, and human and animal excretion [36]. Biomedical waste also includes various anatomical waste like tissues of the body, blood samples, fluids of the human body, and pathological waste. Radioactive waste originating from cancer treatment; cytotoxic waste; microbiological cultures; used syringes, blades, instruments, and lancets; and non-hazardous or general waste like food items, glass, and ceramics are incorporated in 


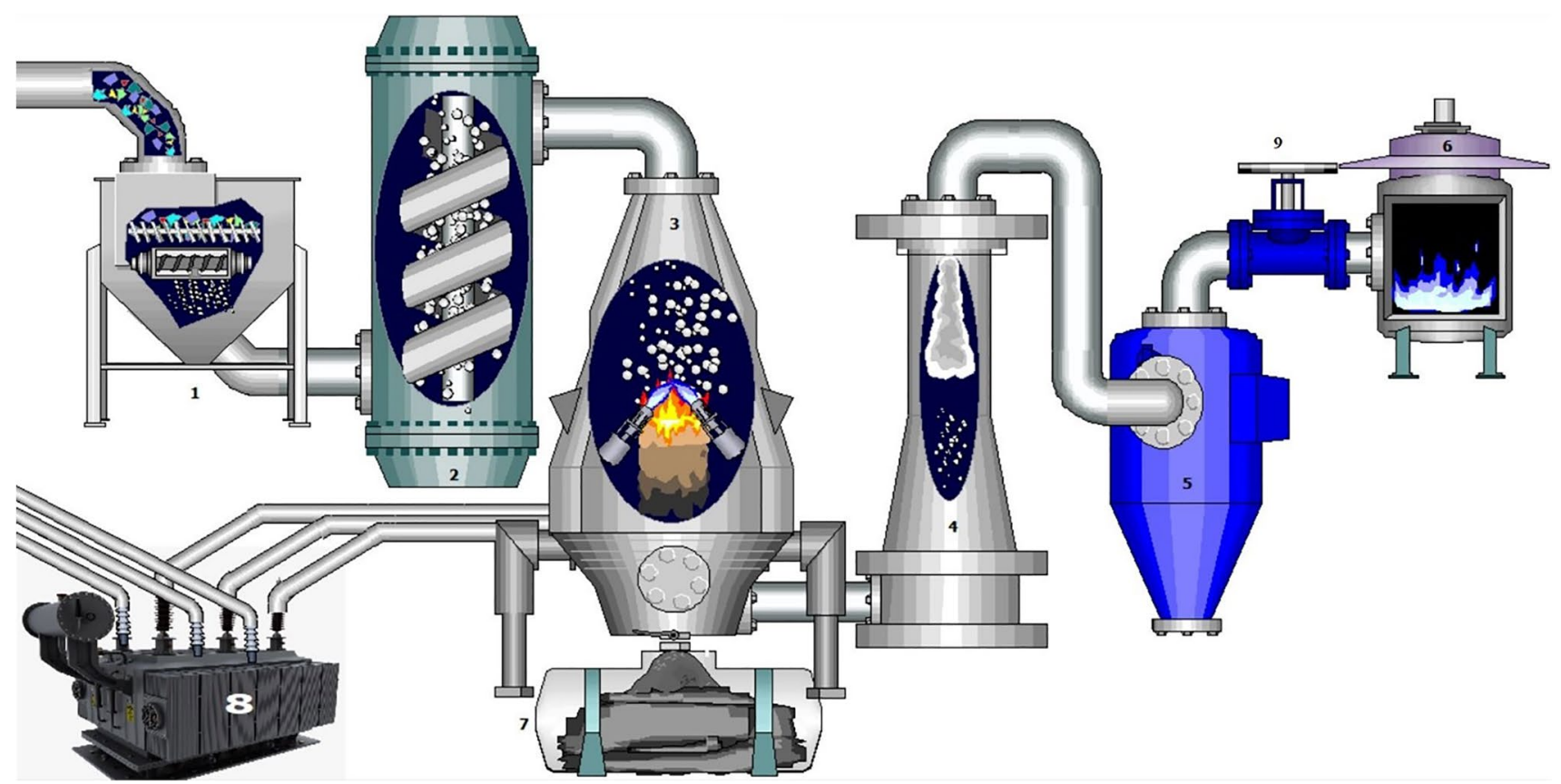

Fig. 1 Plasma gasification setup. 1. Hopper. 2. Shredder. 3. Reactor/gasifier shell. 4. Water scrubber. 5. Cyclone separator. 6. Test flame. 7. Slag removal system. 8. Electric supply. 9. Valve

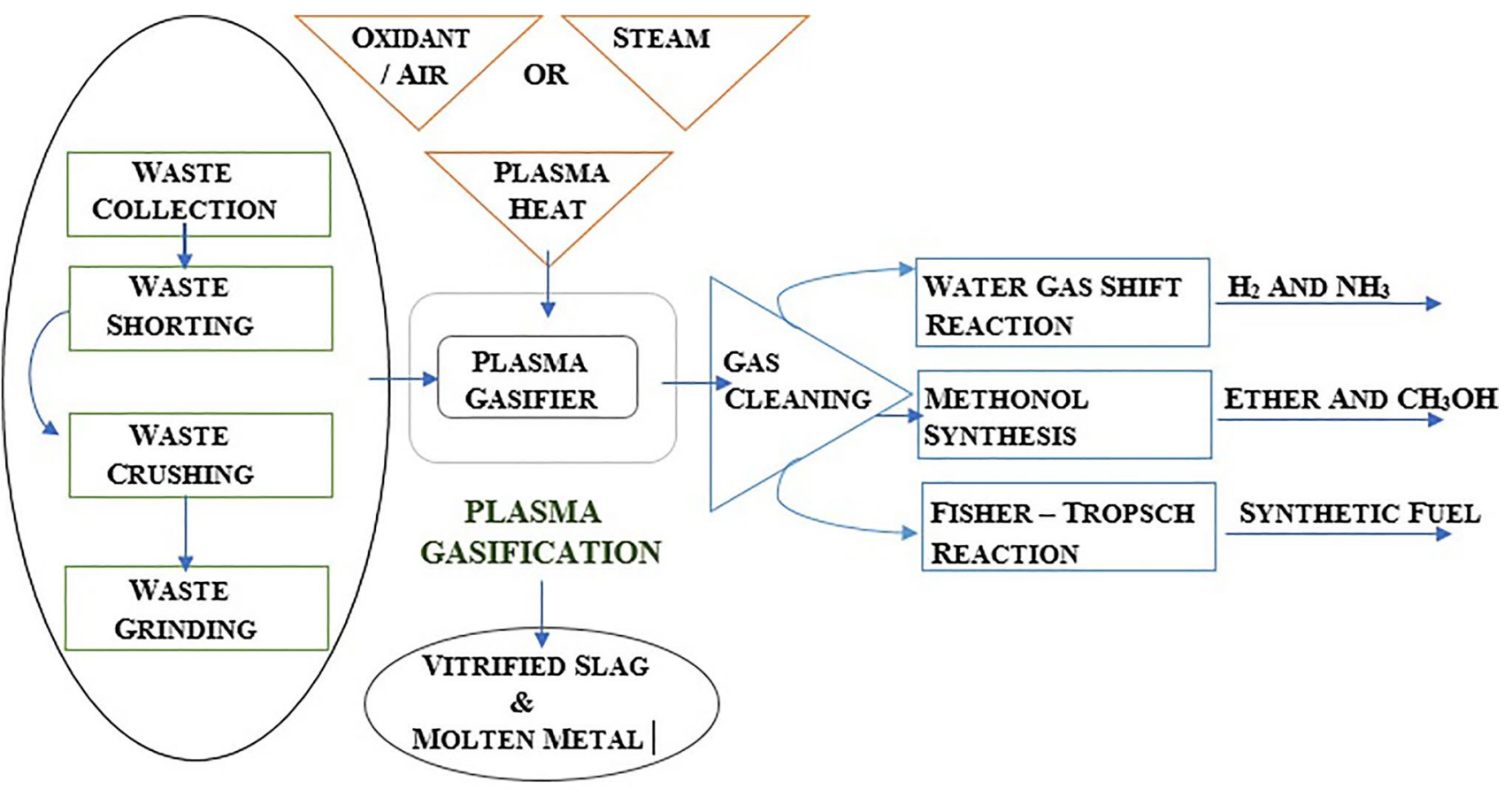

\section{WASTE HANDLING}

Fig. 2 Schematic of plasma gasification

medical waste. Kalogiannidou et al. [37] have studied the composition of biomedical waste and reported that nonhazardous general waste comprises cardboard, plastics, rubber, cloth, and synthetics.
The accumulated medical waste generated by a healthcare unit depends on the type of disease, severity of disease and its contamination, degree of care provided, and waste management practices being followed. The typical medical 
waste generation rate varies for developed and developing countries and is in the range of $0.84-7 \mathrm{~kg}$ per bed per day [38]. The WHO has conducted a global study in 2011 and found that $18-64 \%$ of healthcare units do not use appropriate disposal methods of biomedical waste. The Southeast Asian countries show a similar trend, with almost $56 \%$ of units lacking standard disposal mechanisms [39].

The biomedical waste generation varies according to the tenure of stay of patients in hospitals and the capacity of hospitals. In 2018, out of total medical waste generated by healthcare facilities, around $85 \%$ of the waste was non-infectious waste. Only $15 \%$ of the waste generated is classified as hazardous waste. It was observed that developed countries have a more significant role in hazardous waste generation with a value of $0.5 \mathrm{~kg}$ per bed per day, while low-income countries generate only $0.2 \mathrm{~kg}$ per bed per day [40].

India generated around 619 tons per day of medical waste in 2019, as per data available from the Government of India. This translates to about 0.33 million tons of waste annually from healthcare facilities. Out of this generated waste, 544 tons per day of the waste is disposed of using different methods, while 74 tons per day is released into the environment without proper treatment [41]. A similar study by Ramteke and Sahu [42] has found that almost $28 \%$ of total waste generated is disposed of unscientifically in open areas. Manzoor and Sharma [43] have mentioned the effects of biomedical waste on human health and the environment. The composition of medical waste in Indian scenario is shown in Fig. 3.

The International Clinical Epidemiology Network conducted a comprehensive study to assess the situation of BMW management across various states in India for the period 2009-2012 [44]. The situation was alarming as 82\% of primary healthcare facility (HCF) and 60\% of secondary HCF do not have any credible biomedical waste management system. The tertiary HCF also does not show any improvement, with $54.2 \%$ lacking the adequate disposal strategy. As per the study, the situation is much worse for rural areas than for urban areas, and the reason for such poor

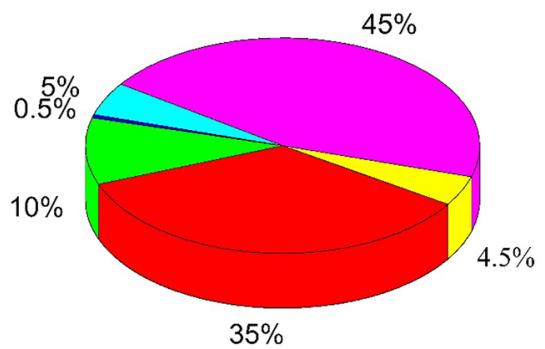

Infectious waste Plastic Glass General waste Disposable Syringes others standards is inadequate training and the low education level of hospital staff.

The Government of India notified the new Bio-Medical Waste Management Rules on March 28, 2016, in compliance with Aarhus and Stockholm Convention. The new rules are much broader and clarified regarding waste categorization introducing color-coding. It mandates that only pretreatment and segregation be done at the HCF level while proper disposal and recycling will occur at Common Bio-Medical Waste Treatment Facility [39].

A study was conducted with a modified WHO tool to evaluate the waste management practices in Punjab, India. The study found that the public sector has more compliance with $67.2 \%$ as against the private sector with $40.4 \%$. Both sectors show $100 \%$ compliance at the secondary level [45].

\subsection{Biomedical waste classification}

The biomedical waste is classified according to the various risks, i.e., physical, biological, chemical, and radiological. It poses to the environment and people. Based on the above criteria, biomedical waste is categorized into non-hazardous waste, i.e., general and hazardous waste. Healthcare waste that is mostly general, i.e., food, paper, leather, cloth, cotton, gauge, and glass, which carries a shallow risk of spreading infection is termed as non-hazardous general waste. These types of wastes are segregated with other general waste and are mostly treated without any procedure like municipal solid waste treatment. The biomedical waste classification is represented in Fig. 4.

The hazardous or infectious wastes are those wastes that can spread infection and have significant environmental and health risks associated with them. These types of waste require safe handling, disposal, and treatment as per the biomedical rules notified by statutory bodies. These wastes contain pathological microorganisms, which can spread disease after exposure. Needles, various syringes, lancets, scalpels, knives, test tubes, broken glass, human and animal cell cultures, amniotic and other body fluids, saliva, blood samples, and pathological waste are included in these wastes.

Hazardous waste further includes chemical waste, radioactive waste, and cytotoxic waste. Chemical waste is the waste that is generated mainly from pharmaceutical preparations. They are termed hazardous if they have one or more of the following listed properties: toxic, corrosive, flammable, reactive, explosive, and oxidizing. Radioactive waste is mainly generated by radioactive compounds used in oncological treatment. They need to be handled carefully in specially designed lead containers. The cytotoxic waste is waste with genotoxic properties, an example being cytotoxic drugs used in oncological treatments.

As a global healthcare waste project, a study was done by the WHO has stated that out of total biomedical wastes

Fig. 3 Composition of BMW in India (source: [43]) 
Fig. 4 Schematic classification of biomedical waste

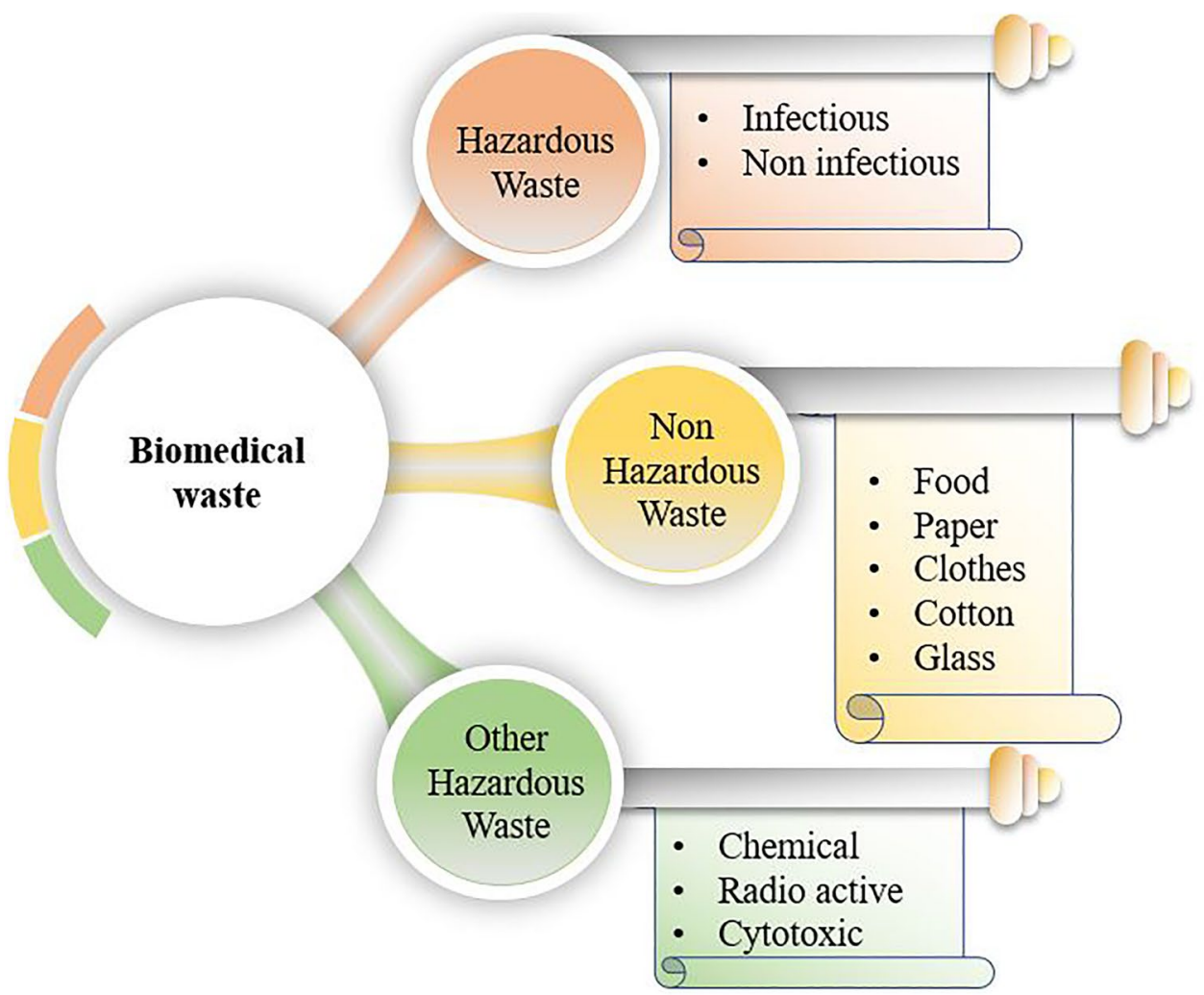

generated globally, $85 \%$ is general or non-hazardous waste and only $10 \%$ accounts for infectious waste. Chemical and radioactive wastes account for 5\% [46]. However, in India, this value could be in the range of $15-35 \%$ due to poor segregation at the source, leading to mixing infectious with general waste [38].

\section{COVID-19 pandemic ramifications on biomedical waste}

The world has seen the emergence of a new strain of coronavirus emerging from Hubei Province, China. This new strain has infected people with symptoms similar to pneumonia [47]. The coronavirus was the third outbreak after SARSCoV-1 in 2002 and MERS-CoV in 2012. WHO DirectorGeneral declared the outbreak a Public Health Emergency of International Concern on January 30, 2020. The number of cases has been reported to be 356 million worldwide as per data accessed within the WHO database on January 27 , 2022. The spread of the virus is so alarming that almost every country in this world is affected, with more than 5.6 million reported deaths. Southeast Asia reported more than 50 million cases, with a massive chunk of cases coming from India, with 40 million reported to date [46].

The main routes of coronavirus transmission are direct contact and respiratory droplets from the mouth. Several precautions like wearing a mask, maintaining social distancing norms, sanitizers and sprays, and aggressive testing are suggested to contain the spread globally. The COVID-19 shows four stages of transmission, imported cases from other countries in stage 1 , local transmission in stage 2 , community transmission being stage 3 , and epidemic being stage 4 [48].

The survival of coronavirus saw a large-scale variation of $2 \mathrm{~h}$ to 9 days. The survival time of the virus on the surface depends on the type of surfaces like plastics, wood, and metals; the temperature and relative humidity of surroundings; and the strain of the virus in circulation [46]. The survivability of coronavirus on the plastic surface is $6.8 \mathrm{~h}$ as against the paper, where it is just $3 \mathrm{~h}$. Other surfaces like cloth (2 days) and stainless steel $(5.6 \mathrm{~h})$ show a great degree of variation depending upon several factors [49, 50]. The survival time of coronavirus is an essential factor in COVID-19 waste management as it facilitates segregation and safe handling of biomedical waste according to the requirement.

The COVID-19 pandemic has severely affected waste management principles and supply chains globally. Wuhan City, the pandemic's epicenter, experienced a 6-fold increase in biomedical waste, 40 to 247 tons per day. Rural communities in the UK saw a rise of $300 \%$ in waste [18]. Shanghai, a megacity in China with 3.3 tons per day, has reported 11.2 times increasing hazardous waste generation [51]. The State Council of China has estimated an increase of 469 tons per 
day of medical waste attributed to the corona pandemic [52]. Prominent Southeast Asian cities also experienced a rise from 154 to 280 tons per day. These collectively contributed around 864 tons of BMW per day during the COVID-19 outbreak [53]. Malaysia is observing an increase of $30 \%$ in its clinical waste generation [54]. Iran is also observing an increase in infectious medical waste generation from 0.68 to $5 \mathrm{~kg}$ per bed per day [55]. South Korea has generated 2000 tons of COVID waste until May 2020. The situation in the USA is more worrisome, with an increase from 2.5 million to 5 million tons per year [36].

The COVID-19 pandemic has similarly impacted India, increasing 140-350 tons of biomedical waste daily [57, 58]. The impact of COVID-19 on biomedical waste generation is depicted in Fig. 5.

The inefficiencies of food supply chains during the COVID-19 pandemic have created an unexpected shift in food access and food loss and waste (FLW). Food waste generated from hospitals constitutes an integral part of BMW. During the lockdown period, households have been the primary source of FLW, increasing almost $12 \%$. Online food demand shot up by $80 \%$ during this period. It has increased food and packing waste, including single-use plastics and paper packaging [59].

The rise in demand for PPE can be seen from the fact that China produced 110 million face masks in February 2020, an increase of around $450 \%$. As of October 2020, China has supplied almost 18 billion face masks and 1.7 billion PPE [54]. N95 mask has seen a demand of 1.6 million from the current requirement of 0.2 million [60]. The WHO has studied the monthly need for PPE and estimated that healthcare workers would need 89 million masks, 76 million gloves, 30 million gowns, and 1.6 million goggles during the COVID-19. A similar study for people in Italy has estimated a need of 1 billion face masks and 0.5 billion gloves monthly [16, 61]. Benson et al. [56] have estimated that around 3.4 billion face masks and PPE kits are discarded daily. The region-wise distribution can be seen in Fig. 6. The single-use face masks, gloves, boots, PPE kits, goggles, face shields, etc., comprise mainly low-density polyethylene, polyvinyl
Fig. 5 Impact of COVID-19 on biomedical waste generation (sources: [20, 22, 36, 41, 56])

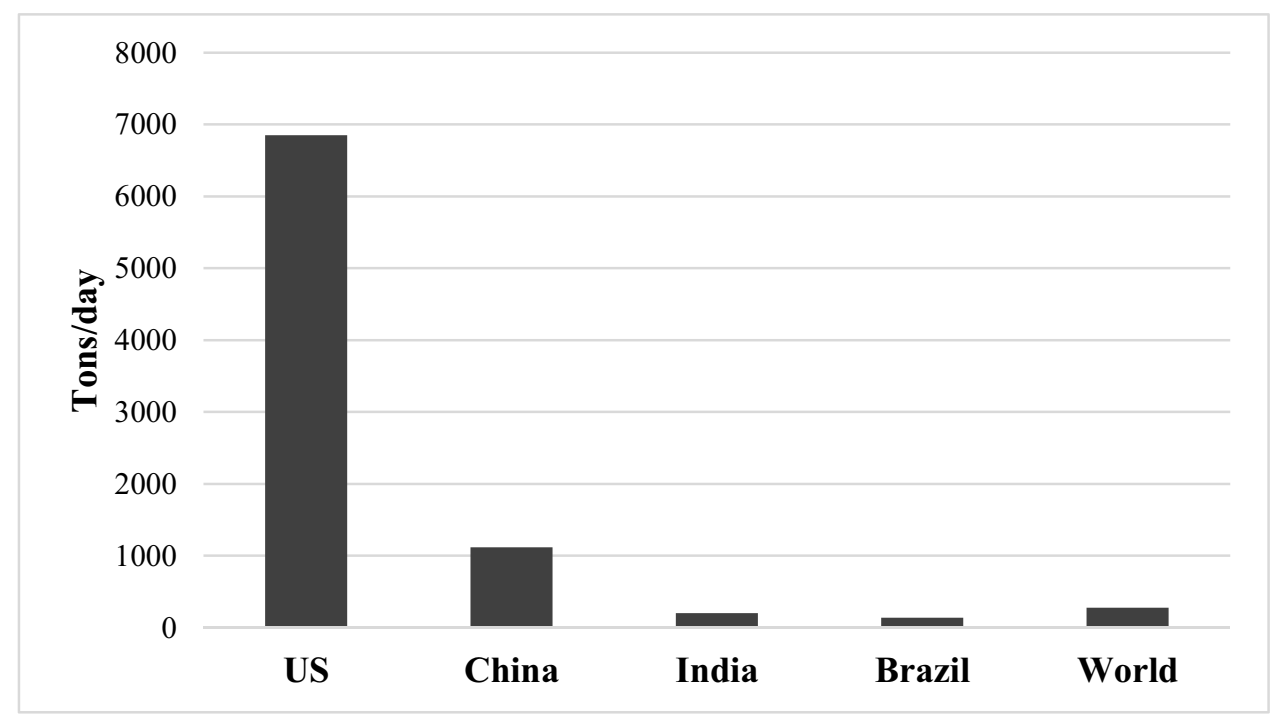

Fig. 6 Estimated number of discarded face masks region-wise

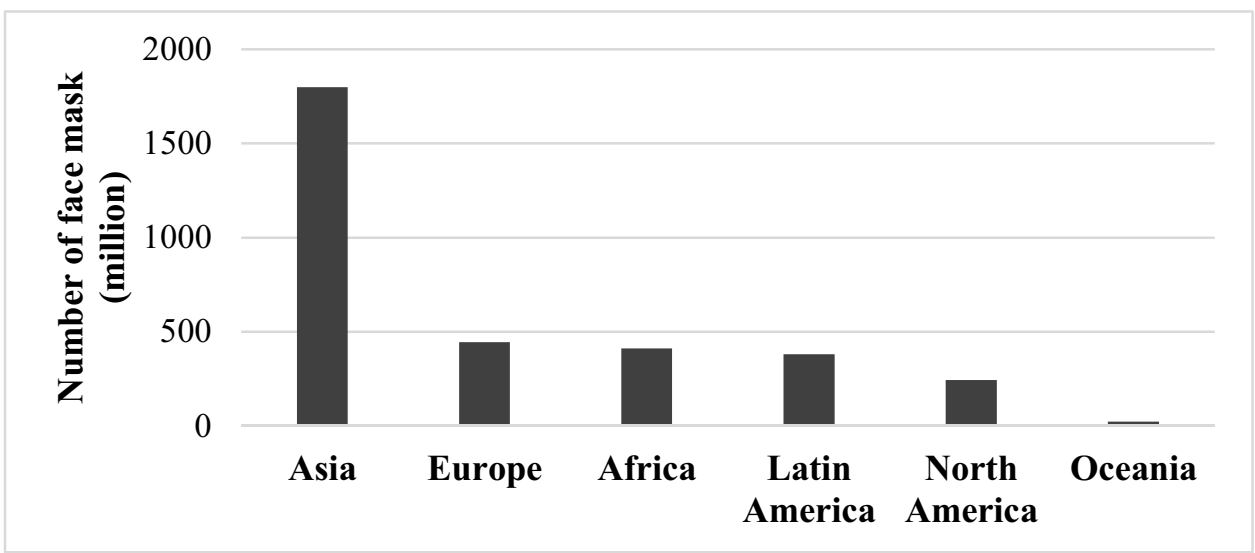


chloride, polycarbonate, and other components, increasing the percentage of plastic content in biomedical waste [41].

The UNEP has estimated an increase of $0.5 \mathrm{~kg}$ per bed per day of plastic medical waste generation amid the COVID19 pandemic worldwide [16]. Even after the pandemic, this surge in demand for PPE like facemask and gloves is not intended to decline and may record a CAGR of $20 \%$ until 2025 [36]. Plastic waste generation is on a steep incline, with almost 1.6 million tons generated worldwide [62]. Hantoko et al. [54] have estimated the total weight of discarded facemask generated per day and found it to be 2331 tons per day for India, only assuming a weight of $3 \mathrm{~g}$ for each discarded facemask.

The COVID-19 pandemic has led to the prioritization of human health over environmental health, and waste management strategies are getting postponed or reversed in many countries globally. Hygiene and preventive concerns have led to a significant increase in demand for food packaging. The ban of single-use plastics (SUP) has been delayed in Newfoundland and Labrador provinces in Canada, New York, Maine, Delaware, and others in the USA, UK, and Portugal. Several others like Massachusetts and New Hampshire in the USA have either reintroduced it or banned reusable amid COVID-19 concerns [61]. Waste management practices in affected European countries like Italy which have been confined to infected persons are prohibited from segregating their waste [63]. China has also suspended environmental standards for its small industries to expedite their recovery [50]. Indian municipalities were also at the receiving end due to increased plastic waste amid the COVID-19 pandemic. Corburn et al. [64] have reported a rise in uncontrolled landfilling and burning of plastic waste in several Indian municipalities.

To contain COVID-19 transmission, countries have mostly resorted to a social distancing between individuals, quarantining, avoiding public gatherings, promoting work from home, closing education institutions and promoting online classes, restricting visits to malls, restaurants, etc. This measure has fostered a culture of online shopping and food delivery among consumers. Food order delivery from stores has shot up by almost $80 \%$ during this duration. South Korea has reported an increase of $92.5 \%$ and $44.5 \%$ in online food orders and daily necessities. India, China, Italy, and Germany have observed a $12-57 \%$ increase in online shopping activities during the same duration. The USA has reported a 30\% rise in online shopping. An online shopping firm, Amazon e-commerce services, has $26 \%$ year-on-year sales in their first quarter [50]. Most packaging is done in single-use plastics like thin films and foams. The packaging in multi-layered plastics is also harmful as they possess very low recyclability due to polystyrene, low-density polyethylene, etc. [41]. Most medicines cover use of singleuse plastics, tablets, capsule covers, containers, and sample collectors. All these will lead to the accumulation of biomedical plastic waste in the environment.

\section{Treatment methods}

The biomedical waste treatment requires special handling, transportation, and safe disposal strategies. The global healthcare waste project initiated in August 2008 was jointly implemented by the WHO in cooperation with UNDP for seven selected countries including India. As per the study, total BMW generation varies from 2 to $4 \mathrm{~kg}$ per bed per day. Infectious waste constitutes a fraction of this waste with a mere $0.2-0.4 \mathrm{~kg}$ per bed per day. The average bulk density was found to be $100-200 \mathrm{~kg}$ per cubic meter [65]. Biomedical waste collection in India is still developing as only $44 \%$ of healthcare facilities have agreed to have a waste collection facility. Thirty-two percent of healthcare units dump their waste in dustbins provided by urban bodies [66]. Much garbage is dumped openly in nearby landfills and thus could not make up to the treatment facilities. Poor segregation of hazardous waste is also an issue. The hazardous nature of biomedical waste should be considered while selecting a reliable and authentic waste treatment method. The infectious nature of this waste possesses not only human health concerns but also a significant risk to the environment as observed in the case of the COVID-19 pandemic.

Three approaches have been defined for BMW treatment, i.e., an onsite treatment where healthcare facility treats its waste, cluster treatment where waste is treated in cluster cater for the local area, and central treatment in which dedicated treatment plants handle the BMW. Types and quantity of waste, technological capabilities, treatment efficiency, capacity, volume mass reduction, O\&M requirement, skill requirement, and capital cost are factors that affect the selection of treatment methods.

Several studies have been conducted to evaluate the treatment options of biomedical waste. Incineration is widely utilized to dispose biomedical waste as it is safe and effective $[67,68]$. Incineration is mainly used with no dearth of investment and treats almost 59-60\% of biomedical waste globally [12]. Chemical or steam disinfection is a preferable option for small waste disposal quantities [2].

The WHO has mandated incineration for the disposal of PPE and other infectious waste made from plastics [50]. However, medical waste incineration is a harmful method of waste disposal as it produces toxic compounds like polychlorinated dibenzodioxins (PCDDs) and polychlorinated dibenzofurans (PCDFs) at low temperatures, which are carcinogenic. The various factors like low-temperature range, inappropriate residence time, the chlorine content in waste feedstock, and de novo synthesis primarily respond to the dioxin and furan generations [69]. Apart from generating 
toxic gases like $\mathrm{CO}, \mathrm{CO}_{2}, \mathrm{SO}_{x}, \mathrm{NO}_{x}$, and $\mathrm{PM}$, it also produces polycyclic aromatic hydrocarbons that vary from 3377 to $11,390 \mathrm{ng} / \mathrm{Nm}^{3}$ [70]. The pollution control devices are used to contain the emission of these harmful gases within stringent statutory limits, which adds up to the incinerator cost.

Autoclaving method using steam sterilization is the second most preferred, with a $20-37 \%$ share [12]. Autoclaving is an environmentally friendly technology and converts infectious waste into non-infectious ones. The main issue with autoclaving is that it does not provide volume reduction. Thus, the output needs to be compressed and disposed of in landfills, which consumes extra energy. Other waste disposal methods are microwave treatment, chemical disinfection, biological disinfection, landfilling, burning, and plasma gasification, with less frequent usage and a combined share of 4-5\% [67].

During recent years of development, plasma gasification of biomedical waste emerged as a promising technology for the treatment of BMW [23, 71-74]. Wang et al. [2] have recommended the usage of plasma gasification for the treatment of COVID-19 waste as the SARS-CoV-2 can spread quickly. This technology has combined the benefit of volume reduction up to $95 \%$, mass reduction of $90 \%$, significant low emissions, and residual inert $[26,36]$. The plasma gasification has shown higher efficiency in the treatment of BMW than conventional incineration, which makes it more suitable and promising in its future applications [23].

Plasma gasification has been compared with incineration as it is an established and most widely used technology for treating biomedical waste in Table 2. The plasma gasification technology for biomedical waste treatment is quite beneficial as it provides a clean output of syngas, less toxic emissions, slight char, and tar, and can disintegrate almost any medical compound present in the waste.

\section{Plasma gasification of biomedical waste}

\subsection{Modeling of plasma gasification}

Favas et al. [35] have utilized Aspen Plus to develop a plasma gasification model. The entire process is divided into four sections: inlet, drying of feedstock, pyrolysis, and gasification for simulation. The model was developed to minimize the Gibbs free energy for calculating syngas constituents. Gibbs free energy at equilibrium for plasma gasification is defined by the following equation $[35,77]$.

$G^{t}=\sum_{i=1}^{N} n_{i} \Delta G_{f, i}^{0}+\sum_{i=1}^{N} n_{i} R T \ln \left(\frac{n_{i}}{n_{\text {total }}}\right)$

where $G^{t}$ is Gibbs free energy of the system; $n_{i}$ and $n_{\text {total }}$ are the number of moles of species $i$ and the total number of moles of all species in the syngas, respectively; $R$ is the universal gas constant; and $T$ is temperature. The superscript 0 denotes the standard thermodynamic property. Eq. (2) is solved for the values of $n_{i}$ for which the system's total Gibbs free energy is minimized. To minimize the Gibbs free energy, the Lagrange multiplier method given in Eq. (3) is used $[33,78,79]$.
Table 2 Comparison of incinerator with plasma gasification

\begin{tabular}{|c|c|c|c|}
\hline Parameters & Incineration & Plasma gasification & Source \\
\hline \multicolumn{4}{|l|}{ Operating parameters } \\
\hline Temperature (K) & $1000-1500$ & Up to 3000 & [36] \\
\hline Stoichiometric ratio & $>1$ & $<1$ & [75] \\
\hline Sterilization efficacy & High & Very high & [75] \\
\hline Gross electrical efficiency (\%) & $18-26$ & Up to 31 & {$[22,76]$} \\
\hline Volume reduction $(\%)$ & 90 & 95 & {$[22,26]$} \\
\hline \multicolumn{4}{|l|}{ Environmental parameters } \\
\hline $\mathrm{PCDD} / \mathrm{PCDF}\left(\mu \mathrm{g} / \mathrm{Nm}^{3}\right)$ & $<0.0983$ & $<0.00925$ & [74] \\
\hline $\mathrm{NO}_{x}\left(\mu \mathrm{g} / \mathrm{Nm}^{3}\right)$ & $40-100$ & 150 & [74] \\
\hline $\mathrm{SO}_{x}\left(\mu \mathrm{g} / \mathrm{Nm}^{3}\right)$ & 40 & 26 & [74] \\
\hline $\mathrm{HCl}\left(\mu \mathrm{g} / \mathrm{Nm}^{3}\right)$ & & $1-8$ & [74] \\
\hline $\mathrm{PM}\left(\mu \mathrm{g} / \mathrm{Nm}^{3}\right)$ & 20 & 12.5 & [74] \\
\hline \multicolumn{4}{|l|}{ Economic cost (per ton) } \\
\hline Capital cost (million USD) & 0.23 & 0.2 & [74] \\
\hline Operation cost (million USD/year) & 0.016 & 0.017 & [74] \\
\hline \multicolumn{4}{|l|}{ Readiness level } \\
\hline Technology readiness level & 9 & 8 & [74] \\
\hline Community readiness level & 9 & 5 & [74] \\
\hline
\end{tabular}


$\frac{\partial L}{\partial n_{i}}=\Delta G_{f, i}^{0}+n_{i} R T \ln \left(\frac{n_{i}}{n_{\text {total }}}\right)+\sum_{j=1}^{m} \lambda_{j} a_{i j}=0$

where $L$ and $\lambda_{j}$ denote the Lagrange function and Lagrange multiplier in the equation, respectively, and $a_{i j}$ is the atoms of $j$ th element in a mole of $i$ th species. Eq. (3) denotes the equilibrium equations for each specific species of the system.

Zitouni-Petrogianni and Voutsas [80] have modified a mathematical model based on gasification to include the thermodynamic analysis in the model. This model was based on the model developed by Mountouris et al. [81] in their study. The modified model proves to be beneficial in predicting various concentrations of gases arising out of plasma gasifiers. The modified model was applied as a case study for a plasma gasification plant of 750 tons per day in Greece. The model prediction is confirmed with the process real-time data of the plant. Another model based on equilibrium-based gasification was developed on Aspen Plus. A comparison between entrained flow and plasma gasification has been made. The results indicate that various gasification characteristics like cold gas efficiency, synthesis gas composition, and heating value were better for plasma gasification than entrained flow gasification [82].

A similar model was developed for municipal sludge to hydrogen conversion utilizing plasma gasification coupled with chemical looping. The hydrogen production is significantly higher with plasma gasification than plasma gasification coupled with chemical looping [83]. The hydrogen is produced by utilizing microalgae in a plasma gasifier. Aspen Plus simulation for the above study has obtained an optimal value of steam-to-biomass ratio of 0.354 for raw microalgae [84].

Numerical investigations were carried out for gasification of medical waste in plasma reactor at different equivalence ratio values. Three different waste samples of varying carbon contents were used, and gasification was carried out at equivalence ratios varying between 0.1 and 0.5 . Maximum hydrogen generation was observed at an equivalence ratio of 0.1 for all samples [20].

\subsection{Plasma gasification treatment of biomedical waste}

A significant change has been observed in medical composition in recent times. COVID-19 pandemic has increased the percentage of plastics and polymers in waste due to heavy usage of PPE kits, face shield, gown, gloves, masks, disposable bags, and other safety harnesses. Precautions against diseases like AIDS, hepatitis, and Ebola also significantly increase the number of plastics in medical waste. The COVID-19 pandemic has severely increased plastic waste generation, with almost 1.6 million tons of plastic generated every day globally [62]. Plastic content in medical waste has risen from 10 to $30 \%$ in the last decade [85]. The calorific value of medical waste has been thus pushed higher, owing to the rise of plastic. The potential energy recovered per $\mathrm{kg}$ of plastics is around $40 \mathrm{MJ} / \mathrm{kg}$ [17]. Studies have evaluated that the average calorific value of biomedical waste ranges between 12.5 and $16.4 \mathrm{MJ} / \mathrm{kg}$ [86].

Plasma gasification technology has evolved with time and is seen as a promising technology to handle almost all types of medical waste. Owing to its high-temperature operation at $3000{ }^{\circ} \mathrm{C}$, it can kill all the microorganisms. Such hightemperature operation is a good source of ultraviolet radiation, which aids in killing the bacterial and viral loads in the waste. Pharmaceutical ingredients are also destroyed in the process with no traces left [25]. Plasma gasification has been utilized in eradicating cytotoxic medicines, which also offer high resistance to decomposition.

Further reductions in emission in the form of dioxins, benzopyrene, and furans are observed [87, 88]. The only disadvantage with the technology is its heavy electrical power usage in the range of hundreds of $\mathrm{kW}$ to a few MW. The syngas is produced as a byproduct in the whole process of treatment of waste which has several usages. The most promising use of fuel is its utilization as an energy source [89]. The Fischer-Tropsch process is used to convert syngas to liquid fuel. The syngas can be utilized for gas turbine operation or as an input to fuel cells for electricity production. Other products like ammonia, methane, and hydrogen can also produce syngas [23]. Various studies are being conducted to utilize compression ignition engines as a fuel of the next generation. Increased mileage and reduced operation cost of running such engines have been observed by utilizing syngas [90].

Plasma gasification is a relatively newer technology in treating the medical waste field. The output of the plasma gasification process is a gas-like substance that can be used as an input raw material in the construction and infrastructure development industry. Scrap metals in the waste can be recycled as they are recovered in the molten form [74]. The plasma gasification has a high temperature associated, which breaks the complex structures in a simple form addressing the safety concerns to human health and the environment. Syngas is generated as a byproduct in the whole process that can substitute conventional fuels in compression ignition engines [91]. The syngas obtained from plasma gasification is good quality and rich in hydrogen with low tar content [30, 92].

A plasma gasification unit consists of several components and systems used for its smooth functioning. A typical unit has a waste feeding system; chamber of waste processing; solid residues handing system, which also helps remove solid waste; synthesis gas management system; and monitoring and control [25]. The process flow can be depicted in Fig. 7. 


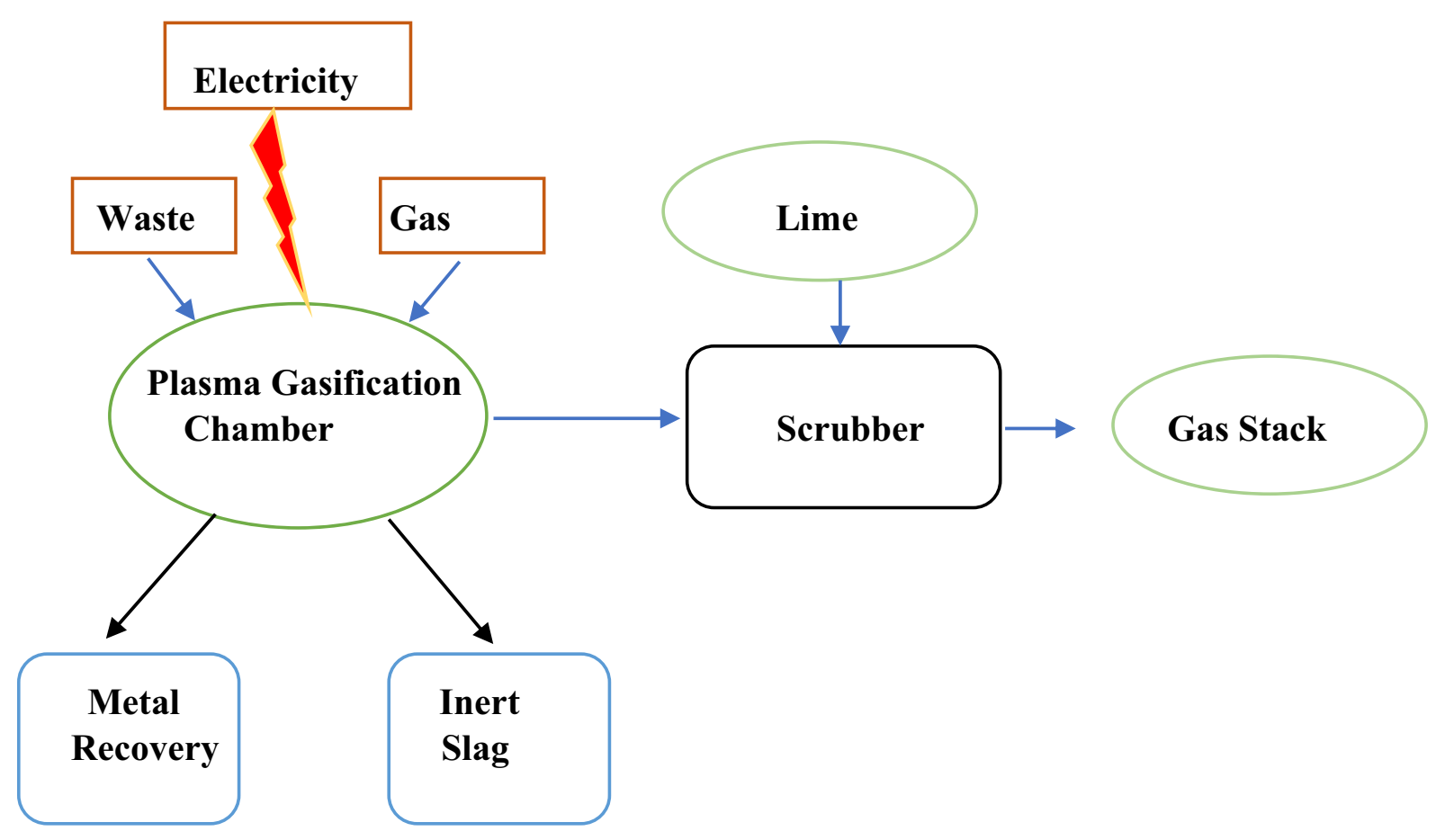

Fig. 7 Plasma gasification process flow diagram

An experimental study with the treatment of medical waste with fly ash has been carried out by varying the weight ratio to obtain minimal waste discharge along with a high-value end product. Feeding only medical waste in the gasifier resulted in slag containing approximately $36 \%$ oxygen, $28.6 \%$ calcium, and $16 \%$ silicon. Co-treating it with fly ash in the ratio of 2:1 shows a similar trend. Increasing the fly ash by varying the ratio shows an increasing amount of transition metals in the slag. Treating the fly ash in a plasma gasifier obtained after co-treatment, also called secondary treatment, gives an enriched amount of heavy metals [93].

A very efficient method uses plasma generated by radiofrequency to treat medical and hazardous wastes and cryogenic pretreatment. In cryogenic pretreatment method, all types of medical wastes are passed through liquid nitrogen chamber and treating material becomes brittle, which is easy to crush and all types of material in medical waste are converted into the same particle size 100 to $600 \mu \mathrm{m}$ and crushed at a temperature of $-80{ }^{\circ} \mathrm{C}$. Particle of similar size is easy to treat via RF plasma treatment method [94].

The amount of synthesis gas obtained varies with the temperature in plasma gasifier. Tavares et al. [79] have suggested that plasma gasification is most favorable for syngas production at high temperatures. The maximum yield has been observed at a temperature not more than $1300{ }^{\circ} \mathrm{C}$ as per the calculations done by Messerle et al. [23]. A separate arrangement of plasma gasification in air and steam medium has been made with bone tissue, and the results obtained show that the concentration of syngas is not more than 54\% and $85 \%$ (volume percent). The heat of combustion for synthesis gas produced in these two mediums is $3510 \mathrm{~kJ} / \mathrm{kg}$ and $5664 \mathrm{~kJ} / \mathrm{kg}$, respectively. No harmful impurities are found in the byproduct of plasma gasification as observed with $\mathrm{X}$-ray analysis.

An experimental investigation on solid waste, which included medical waste, reported the composition of carbon monoxide (73.4\%), hydrogen (6.2\%), nitrogen (29.6\%), and sulfur $(0.8 \%)$ as volume percentage composition of synthesis gas. The total concentration of syngas obtained is $69.6 \%$ (volume percentage). The experimental results obtained match accurately with the calculation done by Ustimenko [95]. The electricity consumption varies with the medium used in plasma gasification, and it is calculated for unit consumption basis to be around $1.92 \mathrm{kWh} / \mathrm{kg}$ for air gasification and $2.44 \mathrm{kWh} / \mathrm{kg}$ for steam gasification.

Zhovtyansky and Valinčius [96] have done an extensive study on plasma gasification of waste and concluded it to be a commercially viable alternative based on the ecological benefits it possesses and the total energy efficiency of the system. Plasma gasification is highly efficient in treating hazardous waste, with an efficiency of $99.9 \%$. The overall flexibility of the systems, along with its acceptance of a comprehensive range of waste, makes it an important technology for research purposes. With every ton of solid waste fed into the plasma gasifier, $900 \mathrm{kWh}$ of electricity can be produced [97]. 
The efficiency of an internal combustion engine coupled with a plasma gasifier comes out to be $78.58 \%$. The electricity generation potential for the system has been evaluated to be $31 \%$, i.e., the setup produces $31 \%$ of the electricity required to be fed into a plasma gasifier. The payback period for the whole setup is calculated to be around 6 years which is quite impressive comparing the payback period for hydropower dams is around 20 years [98].

The feasibility of plasma gasification setup compared to incineration has been studied in Portugal. The study covered a comprehensive evaluation and found that plasma gasification is more beneficial considering health safety and environmental. Economic analysis over 20 years provided lower or similar costs for plasma gasification compared to incineration. The annual cash flow was studied and found that plasma gasification is feasible for a life span of 20 years. Plasma gasification requires a high initial investment, but annual revenue exceeds expenses [76].

\section{Conclusion}

The COVID-19 pandemic has thrown open a challenge for medical waste management due to the enormous amount of hazardous medical waste being generated due to precautionary measures against the coronavirus. India is also observing a similar trend with a CAGR of $7 \%$ in medical waste generation and is set to cross the 775 tons per day mark in 2022.

The infectious nature of medical waste makes it difficult to handle. The situation further worsened during the COVID-19 pandemic as the number of plastics increased due to protective equipment usage. The WHO and UNEP have shown concerns for its management and issued various guidelines for its safe disposal. Plasma gasification technology provides a viable alternative for its treatment. Being a flexible technology, it can handle almost any kind of medical waste easily, and volume reduction post-processing of medical waste is seen to be $95 \%$. Such highvolume reduction diminishes the landfill requirement and can be termed a safe alternative as it has negligible impact on the surrounding environment. The vitrified slag generated as a byproduct has several usages and can be used for building aggregates, tiles, bricks, etc. The synthesis gas is produced during the treatment process, which can be utilized to run compression ignition engines. The lack of proper standards and return on investment are some of the concerns that hamper the technology's growth. The technology is nascent in India and requires government intervention for its successful implementation.

\section{Future scope}

There is further scope of studying the cost of technology for treating biomedical waste in India as there is a dearth of work in this field. The different standards and design can be standardized to develop a low-cost alternative to the Indian perspective. The effect of utilizing plasma gasification can be studied for inactivation and residence time of microorganisms. The technology has been confined to lab scale only owing to its high cost and operational difficulties. The Indian waste is unsegregated and has a high moisture content. The real-time data can be assessed by utilizing the setup with general hospital waste on the field. This will help understand and evaluate the operating parameters at a much better scale.

Author contribution Conceptualization, proofreading, and reviewing were performed by Rajneesh Kaushal. Writing of the original draft was performed by Rohit and Amit Kumar Dhaka. Writing with review and editing was performed by Rajneesh Kaushal and Rohit. Visualization was performed by Rohit and Amit Kumar Dhaka.

\section{Declarations}

Conflict of interest The authors declare no competing interests.

\section{References}

1. Bell D, Roberton S, Hunter PR (2004) Animal origins of SARS coronavirus: possible links with the international trade in small carnivores. Philos Trans R Soc Lond B Biol Sci 359(1447):1107-1114. https://doi.org/10.1098/rstb.2004.1492

2. Wang J, Shen J, Ye D, Yan X, Zhang Y, Yang W et al (2020) Disinfection technology of hospital wastes and wastewater: suggestions for disinfection strategy during coronavirus disease 2019 (COVID-19) pandemic in China. Environ Pollut 262:114665. https://doi.org/10.1016/j.envpol.2020.114665

3. Bukhari Q, Massaro JM, D'Agostino RB, Khan S (2020) Effects of weather on coronavirus pandemic. Int J Environ Res Public Health 17:5399. https://doi.org/10.3390/ijerph17155399

4. Sarker S, Khan A, Mannan MM (2016) Urban population and economic growth: South Asia perspective. Eur J Gov Econ 5:64-75

5. Balk D, Montgomery MR, Engin H, Lin N, Major E, Jones B (2019) Urbanization in India: population and urban classification grids for 2011. Data 4:35. https://doi.org/10.3390/data4010035

6. O'Neill B, Ren X, Jiang L, Dalton M (2012) The effect of urbanization on energy use in India and China in the iPETS model. Energy Econ Elsevier 34:339-345

7. Sharma Kapil D, Jain S (2019) Overview of municipal solid waste generation, composition, and management in India. J Environ Eng 145:4018143. https://doi.org/10.1061/(ASCE)EE.1943-7870. 0001490

8. Pujara Y, Pathak P, Sharma A, Govani J (2019) Review on Indian Municipal Solid Waste Management practices for reduction of environmental impacts to achieve sustainable development goals. J Environ Manag 248:109238. https://doi.org/10.1016/j.jenvman. 2019.07.009 
9. Kumar S, Smith SR, Fowler G, Velis C, Kumar SJ, Arya S, et al. (2017) Challenges and opportunities associated with waste management in India. Author for correspondence

10. Ramachandra TV, Bharath HA, Kulkarni G, Han SS (2018) Municipal solid waste: generation, composition and GHG emissions in Bangalore, India. Renew Sustain Energy Rev 82:11221136. https://doi.org/10.1016/j.rser.2017.09.085

11. Joshi R, Ahmed S (2016) Status and challenges of municipal solid waste management in India: a review. Cogent Environ Sci 2:1139434. https://doi.org/10.1080/23311843.2016.1139434

12. Windfeld ES, Brooks MSL (2015) Medical waste management - a review. J Environ Manag 163:98-108. https://doi.org/10. 1016/j.jenvman.2015.08.013

13. Parida A, Capoor MR, Bhowmik KT (2019) Knowledge, attitude, and practices of bio-medical Waste Management rules, 2016; Bio-medical Waste Management (amendment) rules, 2018; and Solid Waste Rules, 2016, among healthcare workers in a tertiary care setup. J Lab Physicians 11:292-299. https:// doi.org/10.4103/JLP.JLP_88_19

14. Souza BCD, Seetharam AM, Chandrasekaran V, Kamath R, Souza BCD, Seetharam AM (2017;0:1-6) Comparative analysis of cost of biomedical waste management across varying bed strengths in rural India. Int J Healthcare Manag. https://doi.org/ $10.1080 / 20479700.2017 .1289438$

15. Janagi R (2015) Scenario of management of medical waste in US and UK: a review. J Global Trends Pharm Sci 6:2328-2339

16. Mahanwar PA, Bhatnagar MP. (2020) Medical plastics waste

17. Klemeš JJ, Van FY, Tan RR, Jiang P (2020) Minimising the present and future plastic waste, energy and environmental footprints related to COVID-19. Renew Sust Energ Rev 127:109883. https://doi.org/10.1016/j.rser.2020.109883

18. You S, Sonne C, Ok YS (2020) COVID-19's unsustainable waste management. Science (80-) 368:-1438

19. Sharma M, Kaushal R (2018:1-19) Advances and challenges in the generation of bio-based fuels using gasifiers: a comprehensive review. Int J Ambient Energy. https://doi.org/10.1080/ 01430750.2018 .1517687

20. Erdogan AA, Yilmazoglu MZ (2021) Plasma gasification of the medical waste. Int J Hydrog Energy 46:29108-29125. https:// doi.org/10.1016/J.IJHYDENE.2020.12.069

21. Cai X, Du C (2020) Thermal plasma treatment of medical waste. Plasma Chem Plasma Process. https://doi.org/10.1007/ s11090-020-10119-6

22. Paulino RFS, Essiptchouk AM, Costa LPC, Silveira JL (2021) Thermodynamic analysis of biomedical waste plasma gasification. Energy 2021:122600. https://doi.org/10.1016/J.ENERGY. 2021.122600

23. Messerle VE, Mosse AL, Ustimenko AB (2018) Processing of biomedical waste in plasma gasifier. Waste Manag 79:791-799. https://doi.org/10.1016/j.wasman.2018.08.048

24. Rohit, Kaushal R, Dhaka AK (2021) Application of plasma gasification technology in handling medical waste as an approach to handle the waste generated by COVID-19 pandemic. Lect Notes. Electr Eng 760:183-197. https://doi.org/10.1007/978981-16-1186-5_15

25. Gomez E, Rani DA, Cheeseman CR, Deegan D, Wise M, Boccaccini AR (2009) Thermal plasma technology for the treatment of wastes: a critical review. J Hazard Mater 161:614-626. https://doi.org/10.1016/j.jhazmat.2008.04.017

26. Ruj B, Ghosh S (2014) Technological aspects for thermal plasma treatment of municipal solid waste - a review. Fuel Process Technol 126:298-308. https://doi.org/10.1016/j.fuproc. 2014.05.011

27. Gabbar HA, Darda SA, Damideh V, Hassen I, Aboughaly M, Lisi D (2021) Comparative study of atmospheric pressure DC, $\mathrm{RF}$, and microwave thermal plasma torches for waste to energy applications. Sustain Energy Technol Assessments 47:101447. https://doi.org/10.1016/J.SETA.2021.101447

28. Cai X, Wei X, Du C (2020) Thermal plasma treatment and coprocessing of sludge for utilization of energy and material. Energy Fuel. https://doi.org/10.1021/acs.energyfuels.0c00572

29. Watson J, Zhang Y, Si B, Chen WT, de Souza R (2018) Gasification of biowaste: a critical review and outlooks. Renew Sust Energ Rev 83:1-17. https://doi.org/10.1016/j.rser.2017.10.003

30. Yaliwal VS, Banapurmath NR, Gireesh NM, Tewari PG (2014) Production and utilization of renewable and sustainable gaseous fuel for power generation applications: a review of literature. Renew Sust Energ Rev 34:608-627. https://doi.org/10.1016/j. rser.2014.03.043

31. Janajreh I, Adeyemi I, Raza SS, Ghenai C (2021) A review of recent developments and future prospects in gasification systems and their modeling. Renew Sust Energ Rev 138:110505. https:// doi.org/10.1016/j.rser.2020.110505

32. Lemmens B, Elslander H, Vanderreydt I, Peys K, Diels L, Oosterlinck $\mathrm{M}$ et al (2007) Assessment of plasma gasification of high caloric waste streams. Waste Manag 27:1562-1569. https://doi. org/10.1016/j.wasman.2006.07.027

33. Janajreh I, Raza SS, Valmundsson AS (2013) Plasma gasification process: modeling, simulation and comparison with conventional air gasification. Energy Convers Manag 65:801-809. https://doi. org/10.1016/j.enconman.2012.03.010

34. Ren J, Cao JP, Zhao XY, Yang FL, Wei XY (2019) Recent advances in syngas production from biomass catalytic gasification: a critical review on reactors, catalysts, catalytic mechanisms and mathematical models. Renew Sust Energ Rev 116:109426. https://doi.org/10.1016/j.rser.2019.109426

35. Favas J, Monteiro E, Rouboa A (2017) Hydrogen production using plasma gasification with steam injection. Int J Hydrog Energy 42:10997-11005. https://doi.org/10.1016/j.ijhydene.2017.03.109

36. Ilyas S, Srivastava RR, Kim H (2020) Disinfection technology and strategies for COVID-19 hospital and bio-medical waste management. Sci Total Environ 749:141652. https://doi.org/10.1016/j. scitotenv.2020.141652

37. Kalogiannidou K, Nikolakopoulou E, Komilis D (2018) Generation and composition of waste from medical histopathology laboratories. Waste Manag 79:435-442. https://doi.org/10.1016/j. wasman.2018.08.012

38. Taghipour H, Mohammadyarei T, Asghari Jafarabadi M, Asl HA (2014) On-site or off-site treatment of medical waste: a challenge. J Environ Health Sci Eng 12:68. https://doi.org/10.1186/ 2052-336X-12-68

39. Capoor MR, Bhowmik KT (2017) Current perspectives on biomedical waste management: rules, conventions and treatment technologies. Indian J Med Microbiol:157-164. https://doi.org/ 10.4103/ijmm.IJMM

40. WHO (2018) WHO healthcare waste facts 2018. https://www. who.int/news-room/fact-sheets/detail/health-care-waste. Accessed 8 Feb 2018

41. Dehal A, Vaidya AN, Kumar AR (2021:1) Biomedical waste generation and management during COVID-19 pandemic in India: challenges and possible management strategies. Environ Sci Pollut Res Int. https://doi.org/10.1007/S11356-021-16736-8

42. Ramteke S, Sahu BL (2020) Novel coronavirus disease 2019 (COVID-19) pandemic: considerations for the biomedical waste sector in India. Case Stud Chem Environ Eng 2:100029. https:// doi.org/10.1016/j.cscee.2020.100029

43. Manzoor J, Sharma M (2019) Impact of biomedical waste on environment and human health. 31:311-334. https://doi.org/10.1080/ 10406026.2019.1619265

44. INCLEN Program Evaluation Network (IPEN) Study Group (2014) Bio-medical waste management: situational analysis \& 
predictors of performances in 25 districts across 20 Indian states. Indian J Med Res 139:141

45. Devi A, Ravindra K, Kaur M, Kumar R (2019) Evaluation of biomedical waste management practices in public and private sector of health care facilities in India. Environ Sci Pollut Res 26:26082-26089. https://doi.org/10.1007/s11356-019-05785-9

46. WHO (2022) WHO COVID-19 cases worlwide 2022. https:// covid19.who.int/. Accessed 27 Jan 2022

47. Chan JF, Yuan S, Kok K, To KK, Chu H, Yang J et al (2020) A familial cluster of pneumonia associated with the 2019 novel coronavirus indicating person-to-person transmission: a study of a family cluster. Lancet 395:514-523. https://doi.org/10.1016/ S0140-6736(20)30154-9

48. Tabish M, Khatoon A, Alkahtani S, Alkahtane A, Alghamdi J. (2020) Approaches for prevention and environmental management of novel COVID-19

49. Van Doremalen N, Bushmaker T, Morris DH, Holbrook MG, Gamble A, Williamson BN et al (2020) Aerosol and surface stability of SARS-CoV-2 as compared with SARS-CoV-1. N Engl J Med 382:1564-1567

50. Vanapalli KR, Sharma HB, Ranjan VP, Samal B, Bhattacharya J, Dubey BK et al (2020) Challenges and strategies for effective plastic waste management during and post COVID-19 pandemic. Sci Total Environ 750:141514

51. Van Fan Y, Jiang P, Hemzal M, Klemeš JJ (2020) An update of COVID-19 influence on waste management. Sci Total Environ $754: 142014$

52. Sangkham S (2020) Face mask and medical waste disposal during the novel COVID-19 pandemic in Asia. Case Stud Chem Environ Eng 2:100052. https://doi.org/10.1016/j.cscee.2020. 100052

53. Kulkarni BN, Anantharama V (2020) Repercussions of COVID19 pandemic on municipal solid waste management: challenges and opportunities. Sci Total Environ 743:140693

54. Hantoko D, Li X, Pariatamby A, Yoshikawa K, Horttanainen M, Yan M (2021) Challenges and practices on waste management and disposal during COVID-19 pandemic. J Environ Manag 286:112140. https://doi.org/10.1016/j.jenvman.2021.112140

55. Kargar S, Pourmehdi M, Paydar MM (2020) Reverse logistics network design for medical waste management in the epidemic outbreak of the novel coronavirus (COVID-19). Sci Total Environ 746:141183. https://doi.org/10.1016/j.scitotenv.2020.141183

56. Benson NU, Bassey DE, Palanisami T (2021) COVID pollution: impact of COVID-19 pandemic on global plastic waste footprint. Heliyon 7:e06343. https://doi.org/10.1016/J.HELIYON.2021. E06343

57. Ganguly RK, Chakraborty SK (2021) Integrated approach in municipal solid waste management in COVID-19 pandemic: perspectives of a developing country like India in a global scenario. Case Stud Chem Environ Eng 3:100087. https://doi.org/10.1016/j. cscee. 2021.100087

58. Chand S, Shastry CS, Hiremath S, Joel JJ, Krishnabhat CH, Mateti UV (2021) Updates on biomedical waste management during COVID-19: the Indian scenario. Clin Epidemiol Glob Health 11:100715. https://doi.org/10.1016/J.CEGH.2021.100715

59. Aldaco R, Hoehn D, Laso J, Margallo M, Ruiz-Salmón J, Cristobal J et al (2020) Food waste management during the COVID-19 outbreak: a holistic climate, economic and nutritional approach. Sci Total Environ 742:140524

60. Bown CP. (2020) COVID-19: China's exports of medical supplies provide a ray of hope. PIIE Trade Invest Policy Watch 26.

61. Prata JC, Luísa A, Silva P, Walker TR, Duarte AC, Santos TR. (2020) COVID-19 pandemic repercussions on the use and management of plastics. 0-28. https://doi.org/10.1021/acs.est.0c021 78 .
62. Yousefi M, Oskoei V, Jonidi Jafari A, Farzadkia M, Hasham Firooz M, Abdollahinejad B et al (2021:1-10) Municipal solid waste management during COVID-19 pandemic: effects and repercussions. Environ Sci Pollut Res. https://doi.org/10.1007/ s11356-021-14214-9

63. Zambrano-Monserrate MA, Alejandra M, Sanchez-Alcalde L (2020) Indirect effects of COVID-19 on the environment. Sci Total Environ 728:138813. https://doi.org/10.1016/j.scitotenv. 2020.138813

64. Corburn J, Vlahov D, Mberu B, Riley L, Caiaffa WT (2020) Slum health: arresting COVID-19 and improving well-being in urban informal settlements. J Urban Health 97:348-357

65. WHO Global Environment Facility U. (2020) Global Health-care Waste Project

66. Pullishery F, Panchmal GS, Siddique S. (2016) Awareness, knowledge and practices on bio-medical waste management among health care professionals in Mangalore - a cross sectional study

67. Khadem Ghasemi M, Mohd YR (2016) Advantages and disadvantages of healthcare waste treatment and disposal alternatives: Malaysian scenario. Pol J Environ Stud 25:17-25. https://doi.org/ 10.15244/pjoes/59322

68. Ghodrat M, Rashidi M, Samali B (2017) Life cycle assessments of incineration treatment for sharp medical waste. In: Zhang L, Drelich JW, Neelameggham NR, Guillen DP, Haque N, Zhu J et al (eds) Energy Technol. Springer International Publishing, Cham, pp 131-143

69. McKay G (2002) Dioxin characterisation, formation and minimisation during municipal solid waste (MSW) incineration: review. Chem Eng J 86:343-368. https://doi.org/10.1016/S1385-8947(01) 00228-5

70. Das S, Hazra A, Banerjee P. (2020) PCDD/PCDFs: a burden from hospital waste disposal plant; plasma arc gasification is the ultimate solution for its mitigation. Energy Recover. Process. from Wastes, Springer, p. 9-21.

71. Zhang Q, Dor L, Fenigshtein D, Yang W, Blasiak W (2012) Gasification of municipal solid waste in the plasma gasification melting process. Appl Energy 90:106-112. https://doi.org/10.1016/j. apenergy.2011.01.041

72. Messerle VE, Mosse AL, Ustimenko AB (2016) Municipal solid waste plasma processing: thermodynamic computation and experiment. IEEE Trans Plasma Sci 44:3017-3022. https://doi.org/10. 1109/TPS.2016.2601107

73. Surov AV, Popov SD, Popov VE, Subbotin DI, Serba EO, Spodobin VA et al (2017) Multi-gas AC plasma torches for gasification of organic substances. Fuel 203:1007-1014. https://doi.org/ 10.1016/j.fuel.2017.02.104

74. Munir MT, Mardon I, Al-zuhair S, Shawabkeh A, Saqib NU (2019) Plasma gasification of municipal solid waste for waste-tovalue processing. Renew Sust Energ Rev 116:109461. https://doi. org/10.1016/j.rser.2019.109461

75. Babu BR, Parande AK, Rajalakshmi R, Suriyakala P, Volga M (2009) Management of biomedical waste in India and other countries: a review. J Int Environ Appl Sci 4:65-78

76. Ramos A, Berzosa J, Espí J, Clarens F, Rouboa A (2020) Life cycle costing for plasma gasification of municipal solid waste: a socio-economic approach. Energy Convers Manag 209:112508. https://doi.org/10.1016/j.enconman.2020.112508

77. Jarungthammachote S, Dutta A (2008) Equilibrium modeling of gasification: Gibbs free energy minimization approach and its application to spouted bed and spout-fluid bed gasifiers. Energy Convers Manag 49:1345-1356. https://doi.org/10.1016/j.encon man.2008.01.006

78. Koukkari P, Pajarre R (2006) Introducing mechanistic kinetics to the Lagrangian Gibbs energy calculation. Comput Chem Eng 30:1189-1196. https://doi.org/10.1016/j.compchemeng.2006.03. 001 
79. Tavares R, Ramos A, Rouboa A (2019) A theoretical study on municipal solid waste plasma gasification. Waste Manag 90:3745. https://doi.org/10.1016/j.wasman.2019.03.051

80. Zitouni-Petrogianni A, Voutsas E (2021) Modeling, optimization and cost analysis of municipal solid waste treatment with plasma gasification. Environ Process 8:747-767. https://doi.org/10.1007/ S40710-021-00518-Y

81. Mountouris A, Voutsas E, Tassios D (2006) Solid waste plasma gasification: equilibrium model development and exergy analysis. Energy Convers Manag 47:1723-1737. https://doi.org/10.1016/J. ENCONMAN.2005.10.015

82. Mazzoni L, Janajreh I, Elagroudy S, Ghenai C (2020) Modeling of plasma and entrained flow co-gasification of MSW and petroleum sludge. Energy 196:117001. https://doi.org/10.1016/J.ENERGY. 2020.117001

83. Qi H, Cui P, Liu Z, Xu Z, Yao D, Wang Y et al (2021) Conceptual design and comprehensive analysis for novel municipal sludge gasification-based hydrogen production via plasma gasifier. Energy Convers Manag 245:114635. https://doi.org/10.1016/J. ENCONMAN.2021.114635

84. Kuo PC, Illathukandy B, Wu W, Chang JS (2021) Energy, exergy, and environmental analyses of renewable hydrogen production through plasma gasification of microalgal biomass. Energy 223:120025. https://doi.org/10.1016/J.ENERGY.2021.120025

85. Jianjun H, Wenkang G, Ping X (2006) Thermodynamic study of water-steam plasma pyrolysis of medical waste for recovery of $\mathrm{CO}$ and H2. Plasma Sci Technol 7:3148. https://doi.org/10.1088/ 1009-0630/7/6/018

86. Messerle VE, Mossé AL, Nikonchuk AN (2015) Plasmachemical processing of medicobiological wastes. J Eng Phys Thermophys 88:1420-1424

87. Pan X, Yan J, Xie Z (2013) Detoxifying PCDD/Fs and heavy metals in fly ash from medical waste incinerators with a DC double arc plasma torch. J Environ Sci 25:1362-1367. https://doi.org/10. 1016/S1001-0742(12)60196-X

88. Rehmet C, Rohani V, Fulcheri L (2013) Waste gasification by thermal plasma: a review. Waste Biomass Valorization. https:// doi.org/10.1007/s12649-013-9201-7

89. Zamri AA, Ong MY, Nomanbhay S, Show PL (2021) Microwave plasma technology for sustainable energy production and the electromagnetic interaction within the plasma system: a review. Environ Res 197:111204. https://doi.org/10.1016/j.envres.2021. 111204

90. Bates RP, Dölle K (2017) Syngas use in internal combustion engines - a review. Adv Res 10:1-8. https://doi.org/10.9734/AIR/ 2017/32896

91. Hagos FY, Aziz ARA, Sulaiman SA (2014) Trends of syngas as a fuel in internal combustion engines. Adv Mech Eng 6:401587. https://doi.org/10.1155/2014/401587

92. Hameed Z, Aslam M, Khan Z, Maqsood K, Atabani AE, Ghauri M et al (2021) Gasification of municipal solid waste blends with biomass for energy production and resources recovery: current status, hybrid technologies and innovative prospects. Renew Sust Energ Rev 136:110375. https://doi.org/10.1016/j.rser.2020.110375

93. Zeng J, Yue Y, Gao Q, Zhang J, Zhou J, Pan Y (2019) Co-treatment of hazardous wastes by the thermal plasma to produce an effective catalyst. J Clean Prod 208:243-251. https://doi.org/10. 1016/j.jclepro.2018.10.069

94. Paskalov G (2010) RF plasma system for medical waste treatment

95. Ustimenko AB (2017) Plasma processing of model residential solid waste. J Eng Phys Thermophys. https://doi.org/10.1007/ s10891-017-1673-Z

96. Zhovtyansky V, Valinčius V. (2018) Efficiency of plasma gasification technologies for hazardous waste treatment. Gasif Low-Grade Feed 165-89.

97. Pourali M (2009) Application of plasma gasification technology in waste to energy challenges and opportunities 1-6.

98. Paulino RFS, Essiptchouk AM, Silveira JL (2020) The use of syngas from biomedical waste plasma gasification systems for electricity production in internal combustion: thermodynamic and economic issues. Energy 199:117419. https://doi.org/10.1016/j. energy.2020.117419

Publisher's Note Springer Nature remains neutral with regard to jurisdictional claims in published maps and institutional affiliations. 